\title{
Peningkatan Keterampilan Olah Data (SPSS) Pada Mahasiswa DIII Akuntansi Politeknik Harapan Bersama Tegal
}

\author{
Adi Candra Kusuma ${ }^{1}$, Arif Rakhman ${ }^{2}$ \\ 1,2,Program Studi Teknik Komputer, Politeknik Harapan Bersama \\ e-mail: ${ }^{1}$ candraraden45@gmail.com, ${ }^{2}$ cakrakirana7@gmail.com
}

\begin{abstract}
Abstrak
SPSS banyak digunakan dalam berbagai riset pemasaran, pengendalian dan perbaikan mutu (quality improvement), serta riset-riset sains. SPSS pertama kali muncul dengan versi $P C$ (bisa dipakai untuk komputer desktop) dengan nama SPSS/PC+ (versi DOS). Tetapi, dengan mulai populernya system operasi windows. SPSS mulai mengeluarkan versi windows (mulai dari versi 6.0 sampai versi terbaru sekarang).Salah satu kompetensi yang harus dimiliki oleh mahasiswa adalah mampu melakukan penelitian. Hal ini karena mahasiswa adalah sebuah profesi yang menuntut peningkatan pengetahuan dan keterampilan terus menerus sejalan dengan perkembangan pendidikan di lapangan. Setiap bidang pekerjaan selalu dihadapkan pada permasalahan yang selalu berkembang, baik berupa fenomena yang mengundang tanda tanya, maupun kesenjangan antara yang diharapkan dengan kenyataan. Permasalahan tersebut menuntut jawaban dan solusi yang dapat dipertanggung jawabkan. Data yang telah dikumpulkan tidak akan berarti apa-apa bila tidak diolah dan dianalisis, untuk menghasilkan kesimpulan. Salah satu alat penelitian yang digunakan dalam proses pengolahan data penelitian mahasiswa digunakannya SPSS. Hasil dari kegiatan pelatihan pengolahan data memberikan pengetahuan ilmu, meningkatkan keterampilan, melatih pemikiran kreatif mahasiswa dan memudahkan dalam menentuan uji statistika yang digunakan dalam penelitian. Pemilihan menggunakan SPSS karena memiliki kelebihan dibandingkan dengan microsoft excel yaitukemudahan dalam memasukan data, kemudahan dalam melakukan pengolaan data, dan cepat menampilkan output.
\end{abstract}

Kata kunci-Pengolahan data SPSS, Mahasiswa, Politeknik Harapan Bersama Tegal

\section{PENDAHULUAN}

SPSS adalah sebuah program aplikasi yang memiliki kemampuan analisis statistik cukup tinggi serta sistem manajemen data pada lingkungan grafis dengan menggunakan menu-menu deskriptif dan kotak-kotak dialog yang sederhana sehingga mudah untuk dipahami cara pengoperasiannya. Beberapa aktivitas dapat dilakukan dengan mudah dengan menggunakan pointing dan clicking mouse[1].

SPSS banyak digunakan dalam berbagai riset pemasaran, pengendalian dan perbaikan mutu (quality improvement), serta riset-riset sains. SPSS pertama kali muncul dengan versi PC (bisa dipakai untuk komputer desktop) dengan nama SPSS/PC+ (versi DOS). Tetapi, dengan mulai populernya system operasi windows. SPSS mulai mengeluarkan versi windows (mulai dari versi 6.0 sampai versi terbaru sekarang)[2].

Pada awalnya SPSS dibuat untuk keperluan pengolahan data statistik untuk ilmu-ilmu social, sehingga kepanjangan SPSS itu sendiri adalah Statistikal Package for the Social Sciens. Sekarang kemampuan SPSS diperluas untuk melayani berbagai jenis pengguna (user), seperti untuk proses produksi di pabrik, riset ilmu sains dan lainnya. Dengan demikian, sekarang kepanjangan dari SPSS Statistical Product and Service Solutions[3].

SPSS dapat membaca berbagai jenis data atau memasukkan data secara langsung ke dalam SPSS Data Editor. Bagaimanapun struktur dari file data mentahnya, maka data dalam 
Data Editor SPSS harus dibentuk dalam bentuk baris (cases) dan kolom (variables). Case berisi informasi untuk satu unit analisis, sedangkan variable adalah informasi yang dikumpulkan dari masing-masing kasus[4].

Salah satu kompetensi yang harus dimiliki oleh mahasiswa adalah mampu melakukan penelitian[5]. Hal ini karena mahasiswa adalah sebuah profesi yang menuntut peningkatan pengetahuan dan keterampilan terus menerus sejalan dengan perkembangan pendidikan di lapangan[6]. Setiap bidang pekerjaan selalu dihadapkan pada permasalahan yang selalu berkembang, baik berupa fenomena yang mengundang tanda tanya, maupun kesenjangan antara yang diharapkan dengan kenyataan[7]. Permasalahan tersebut menuntut jawaban dan solusi yang dapat dipertanggung jawabkan[8]. Penelitian merupakan suatu bentuk kegiatan ilmiah untuk mendapatkan pengetahuan atau kebenaran[9]. Pengolahan dan analisis data merupakan tahapan penting dalam penelitian[10]. Data yang telah dikumpulkan tidak akan berarti apa-apa bila tidak diolah dan dianalisis, untuk menghasilkan kesimpulan[11].

Politeknik Harapan Bersama merupakan salah satu Perguruan Tinggi Swasta di kota Tegal yang terletak di Jalan Mataram No. 9 Pesurungan Lor Tegal. Kampus ini memiliki 7 program studi diantaranya adalah DIII Akuntansi. Didalam penyelesaian perkuliahan mahasiswa akuntansi, akademik mengharuskan mahasiswa untuk melakukan tugas akhirnya melalui penelitian. Salah satu alat penelitian yang digunakan dalam proses pengolahan data penelitian mahasiswa digunakannya SPSS[12].

Pengolahan data statistik merupakan hal penting bagi mahasiswa Diploma, S1, S2, S3 dan masyarakat umum yang sedang melakukan penelitian. Bagi sebagian besar orang, pengolahan data menjadi beban atau momok yang menyebabkan orang tersebut kesulitan dan kebingungan dalam menyelesaikan penelitian. Pengolahan data ini dapat dikatakan pasti berkaitan dengan ilmu statistik, dan tidak semua orang menguasainya[13]. Pengolahan data statistik sangat terkait dengan teori alat-alat analisis statistik, kapan alat statistik itu digunakan, perumusan model matematis, kriteria pengujian hasil analisis, teknis pengolahannya dengan program statistik, dan pembacaan hasil interpretasi statistik. Terlebih penting lagi adalah bahwa hasil interpretasi statistik tersebut digunakan untuk pengambilan keputusan manajerial, pengambilan keputusan bisnis, rekomendasi kebijakan, dan sebagai dasar evaluasi dan revaluasi bagi organisasi atau perusahaan yang sedang melakukan ekspansi bisnis[14].

SPSS adalah salah satu program yang paling banyak digunakan untuk analisis statistika ilmu sosial. SPSS digunakan oleh peneliti pasar, peneliti kesehatan, perusahaan survei, pemerintah, peneliti pendidikan, organisasi pemasaran, dan sebagainya[15]. Program ini dikenal sangat handal dalam membantu para peneliti untuk melakukan uji dan analisa statistik. Karena kegunaannya maka program ini menjadi program favorit di lingkungan peneliti dan mahasiswa. Sering sekali dijumpai, mahasiswa DIII Akuntansi pada saat pengolahan data penelitian mengalami kesulitan mengolah data sampai dengan menginterpretasikan data yang diperoleh, hal ini dikarenakan i) mahasiswa kurang fokus dalam mengikuti matakuliah metode penelitian, ii) mahasiswa kesulitan mengungkapkan ketidaktahuannya, iii) kurang minatnya terhadap materi pengolahan data, iv) kurangnya praktek dalam pembelajaran pengolahan data SPSS saat kuliah. Dari akibat hal itu, mahasiswa mengambil jalan pintas dengan mengggunakan jasa olah data, sehingga menyebabkan ketika sidang ujian tugas akhir mahasiswa tidak mampu menjelaskan apa yang ditulis dari hasil olah data yang diperoleh.

Bertolak dari hal tersebut, perlu kiranya untuk memberikan pelatihan pengolahan data menggunakan SPSS pada mahasiswa kebidanan untuk menguatkan pemahaman yang berkaitan dengan olah data penelitian. 


\section{METODE}

\subsection{Sasaran Kegiatan PKM}

Khalayak sasaran yang dipilih adalah Politeknik Harapan Bersama Tegal dimana perguruan tinggi swasta yang terdiri dari berbagai jurusan. Pelatihan ini ditunjukan untuk jurusan Akuntansi semester 5 Kelas 5A dan Kelas 5B.

\section{2 Metode Kegiatan}

Kegiatan berupa pelatihan pengolahan data mulai dari penginputan data sampai dengan output data yang diperoleh. Selama praktek pengolahan data SPSS masing-masing mahasiswa menggunakan unit komputer sendiri, yang kemudian diberikan file data yang berisikan latihan-latihan yang dipraktekan. Pelatihan menggunakan metode tutorial yang dijelaskan oleh pemateri.

\section{3 Tahapan Kegiatan PKM}

\section{3.1 Persiapan}

Sebelum kegiatan dilaksanakan maka dilakukan persiapan-persiapan sebagai berikut;(1)Melakukan observasi dan wawancara terhadap kebutuhan mahasiswa Akuntansi;(2) Menemukan masalah yang dialami mahasiswa akuntansi khususnya kesulitan dalam menentukan uji statistika SPSS; (3) Merancang solusi masalah yang dialami mahasiswa akuntansi; (4) Mempersiapkan kebutuhan untuk pelatihan pengolahan data penelitian; (5) Menentukan waktu pelaksanaan dan lamanya kegiatan pengabdian masyarakat.

\section{3.2 Pelaksanaan Kegiatan}

Adapun kegiatan IbM dalam bentuk pelatihan ini dilaksanakan selama 2 hari dan diikuti oleh 30 peserta pada hari tanggal 18 dan 25 Oktober 2015; Waktunya pukul 16.00 sampai dengan 18.00 WIB bertempat di Laboratorium Komputer 2 Kampus Politeknik Harapan Bersama Tegal.

\section{3.3 Evaluasi Kegiatan}

Berdasarkan wawancara, tanya jawab dan pengamatan langsung selama kegiatan pelatihan berlangsung, kegiatan pengabdian masyarakat ini memberikan hasil sebagai berikut; Memberikan pengetahuan ilmu bagi mahasiswa akuntansi kelas 5A Politeknik Harapan Bersama dalam mengolah data penelitian;Meningkatkan ketrampilan bagi mahasiswa akuntansi kelas 5A Politeknik Harapan Bersama membuat instrumen penunjang pengolahan data;Melatih pemikiran kreatif mahasiswa akuntansi kelas 5A Politeknik Harapan Bersama;Memudahkan mahasiswa dalam menentukan uji statistika yang akan digunakan dalam penelitian.

\subsection{Kegiatan Pelatihan}

\section{HASIL DAN PEMBAHASAN}

Materi yang disampaikan pada kegiatan pengabdian masyarakat sebagai berikut: Pengantar statistika, Jenis penelitian, Variabel penelitian, Tipe data penelitian, Populasi dan sampel, Hipotesis penelitian, Statistika penelitian meliputi statistika deskriptif dan statistika parametrik (uji normalitas, uji homogenitas, uji banding/beda/uji t, uji reliabilitas dan validitas, uji korelasi, uji regresi. 


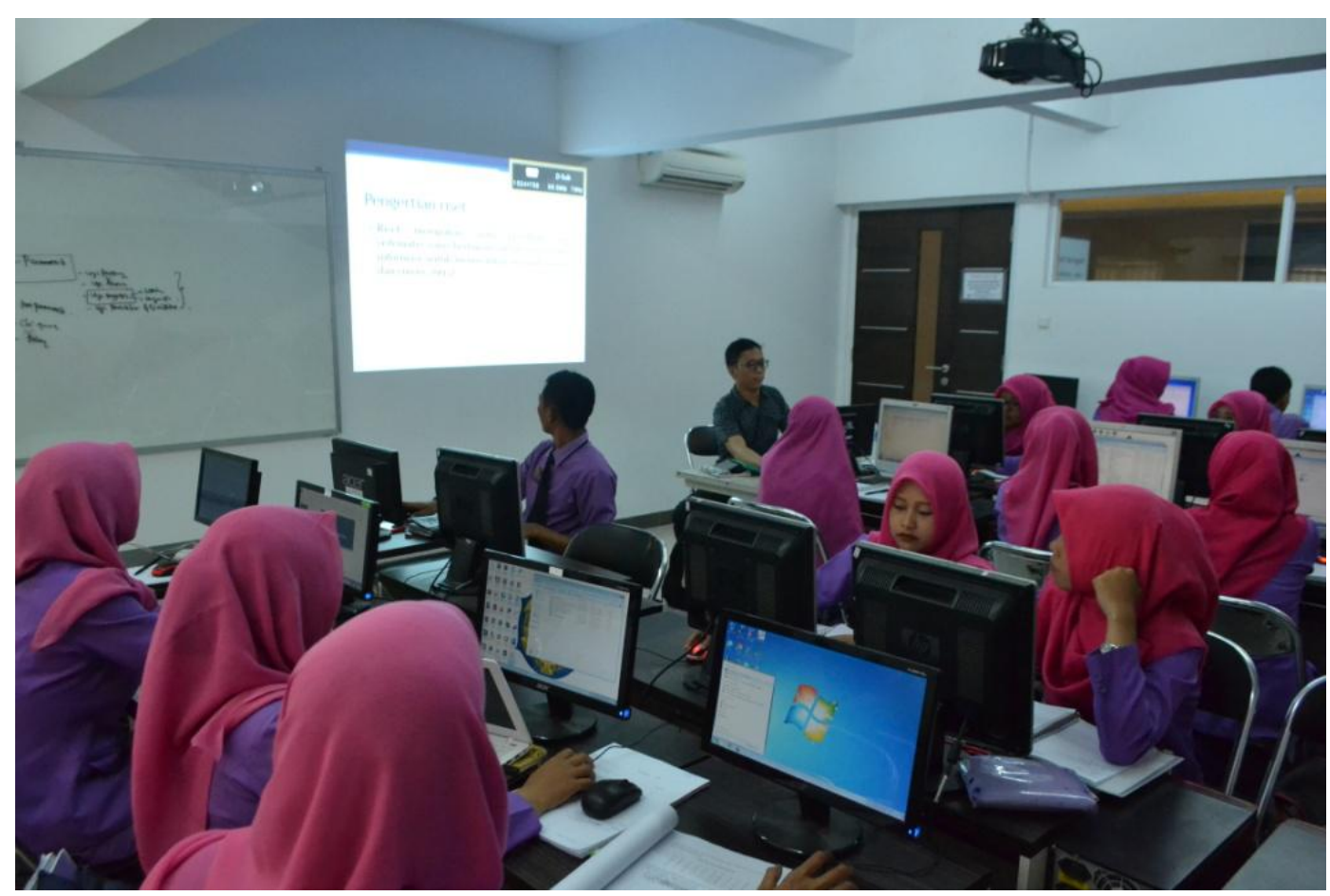

Gambar 1 Pemberian materi kepada peserta

Pada Gambar 1 memperlihatkan proses kegiatan pelatihan yang diikuti oleh para peserta kegiatan. Pada kegiatan ini proses pemberian materi dilakukan oleh tim pelaksana PKM yang terdiri dari para dosen sebagai tim pembantu teknik pelaksanakan PKM.

\subsection{Pendampingan Program}

Dalam kegiatan pelatihan diperlukan pendampingan supaya peserta benar-benar paham dalam mengapilikasikan materi. Yaitu dengan praktek dibimbing sampai menyelesaikan suatu project.

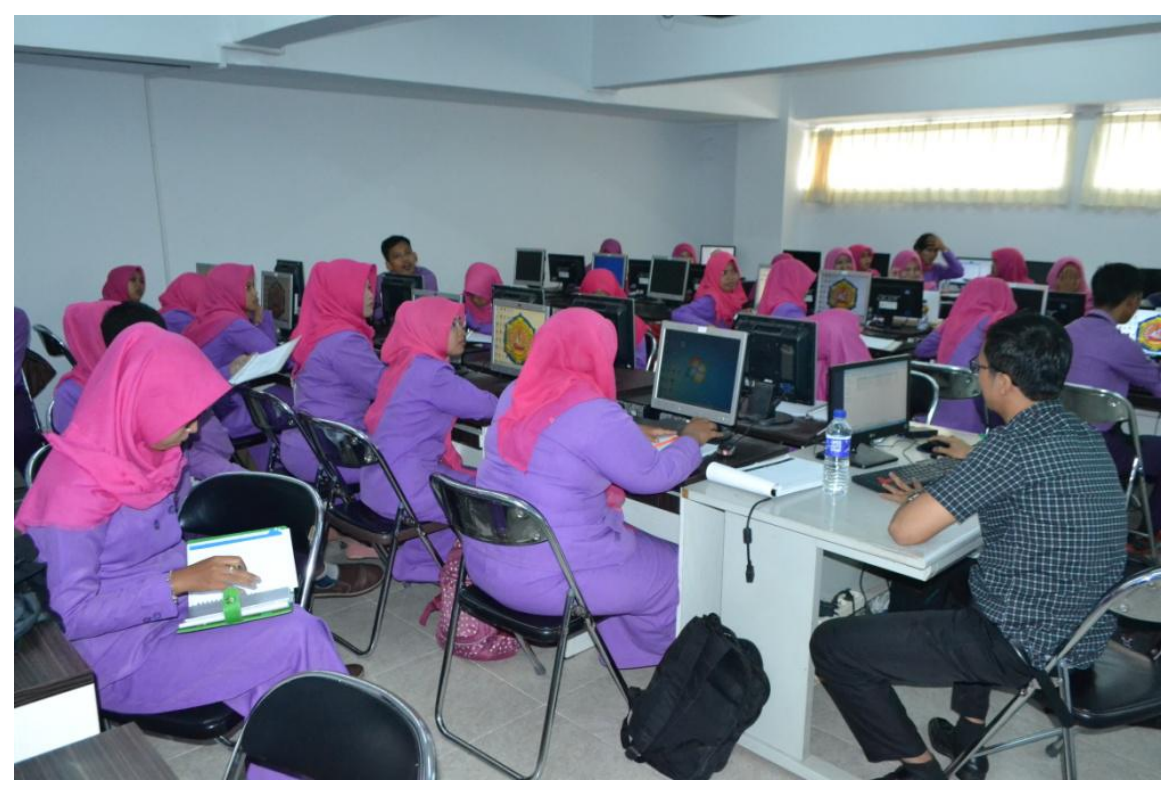

Gambar 2 Proses Pendampingan peserta kegiatan

Pada Gambar 2 memperlihatkan kegiatan pendampingan pada saat proses pelatihan, dimana pendampingan dilakukan oleh tim pelaksana PKM. Pada proses pendampingan ini peserta kegiatan diarahkan dan dibimbing langsung face-to face sehingga harapannya dapat lebih optimal dalam proses. 


\subsection{Capaian Kegiatan}

Pelatihan pengolahan data SPSS penelitian merupakan hal baru bagi mahasiswa akuntansi kelas 5A Politeknik Harapan Bersama, berdasarkan wawancara, tanya jawab dan pengamatan langsung terhadap peserta terlihat sangat antusias mengikuti pelatihan ini. Peserta merasa memperoleh informasi pengetahuan baru sebagai bekal kelak mereka ketika mengerjakan olah data penelitian tugas akhir. Tidak kalah pentingnya, Peserta menyadari bahwa Dalam memahami konsep statistika penelitian harus mengetahui ciri-ciri khusus kasus masing-masing uji statistika. Di dalam pengolahan data sebenarnya selain dengan menggunakan SPSS dapat dilakukan dengan menggunakan Microsoft Excel. Pemilihan menggunakan SPSS karena memiliki beberapa kelebihan dibandingkan program yang lain sehingga menjadi program olah data favorit. Beberapa keunggulan tersebut adalah; Kemudahan dalam memasukkan data, Kemudahan dalam melakukan pengolahan data yaitu hanya dengan memilih uji statistik yang sudah tersedia, Cepat dalam menampilkan output, Output yang mudah dibaca dan dicetak. Contoh penggunaan statistika sebagai berikut:

Tabel 1 Penggunaan SPSS dalam berbagai kegiatan

\begin{tabular}{|c|l|}
\hline $\begin{array}{c}\text { Pengguna } \\
\text { Statistika }\end{array}$ & \multicolumn{1}{|c|}{ Masalah yang di hadapi } \\
\hline Manajemen & $\begin{array}{l}\text { 1.Penentuan struktur gaji dan tunjangan karyawan } \\
\text { 2.Penentuan jumlah persediaan barang, barang dalam proses, barang } \\
\text { jadi } \\
\text { 3.Evalusasi Produktivitas karyawan } \\
\text { 4.Evaluasi kinerja karyawan }\end{array}$ \\
\hline Akuntansi & $\begin{array}{l}\text { 1.Penentuan standar audit barang dan jasa } \\
\text { 2.Penentuan depresiasi apresiasi barang dan jasa } \\
\text { 3.Analisis rasio keuangan perusahaan }\end{array}$ \\
\hline Pemasaran & $\begin{array}{l}\text { 1.Penelitian dan pengembangan produk } \\
\text { 2.Analisis potensi pasar, segmentasi pasar dan diskriminasi pasar } \\
\text { 3.Ramalan penjualan } \\
\text { 4.Efektifitas kegiatan promosi penjualan }\end{array}$ \\
\hline Keuangan & $\begin{array}{l}\text { 1.Potensi peluang kenaikan dan penurunan harga saham,sukubunga } \\
\text { dan reksadana } \\
\text { 2.Tingkat Pengembalian investasi beberapa sektor ekonomi } \\
\text { 3.Analisisis pertumbuhan laba dan cadangan usaha } \\
\text { 4.Analisis resiko setiap usaha }\end{array}$ \\
\hline Ekonomi & $\begin{array}{l}\text { 1.Analisis pertumbuhan ekonomi, inflasi dan suku bunga } \\
\text { 2.Pertumbuhan penduduk dan tingkat pengangguran serta kemiskinan } \\
\text { 3.Indeks harga konsumen dan perdagangan besar }\end{array}$ \\
\hline Agribisnis & $\begin{array}{l}\text { 1.Analisis produksi tanaman, ternak, ikan dan kehutanan } \\
\text { 2.Kelayakan usaha dan skala ekonomi } \\
\text { 3.Manajemen produksi agribisnis } \\
\text { 4.Analisis ekspor dan impor produk pertanian }\end{array}$ \\
\hline
\end{tabular}

\section{KESIMPULAN}

Program olah data ini juga mampu menguji dua tipe data yaitu data kualitatif dan data kuantitatif. Data kualitatif adalah data yang berbentuk kata-kata. Data seperti ini harus dibuatkan ke dalam angka-angka jika ingin dilakukan pengujian dan olah data statistik. Cara membuatnya menjadi angka adalah dengan memberikan skor tertentu pada kata-kata tersebut.

Dengan metode presentasi dan diskusi serta praktek melalui pendampingan terhadap peserta kegiatan, dengan tujuan output yang dihasilkan mahasiswa mampu mengidentifikasi tipe data dengan kegiatan menginput data, mengolah data sampai dengan menginterpretasikan data dalam bentuk deskripsi. 
Beberapa hal yang menjadi faktor pendukung pada kegiatan pelatihan ini adalah Peserta kegiatan sangat antusias/ motivasi mengikuti kegiatan ini sampai selesai, Peserta mempunyai rasa keingintahuan tinggi terhadap materi ini, Peserta mau diberikan arahan dan bimbingan saat pelatihan.

\section{SARAN}

Kegiatan pelatihan seperti ini perlu diadakan setiap tahunnnya adapun saran yang diperlukan adalah Waktu kurang memadai, karena pelatihan sangat singkat dengan materi yang cukup padat sehingga mahasiswa perlu latihan mandiri dirumah., Menentukan waktu pelaksanaan pelatihan pengolahan data dikarenakan berbenturan dengan waktu aktif kuliah mahasiswa, Perlu ada workshop sehingga dapat memberikan pengetahuan lebih jauh tentang buku ajar pembelajaran.

\section{UCAPAN TERIMA KASIH}

Terima kasih kepada Pusat Penelitian dan Pengabdian Masyarakat (P3M) Politeknik Harapan Bersama Tegal yang telah membiayai kegiatan PKM yang telah dilaksanakan ini pada tahun anggaran 2016.

\section{DAFTAR PUSTAKA}

[1] Anoname. 2009. SPSS 17 untuk Pengolahan Data Statistik. Yogyakarta: Andi Offset.

[2] Kuswadi, dan Mutiara, Erna. 2004. Statistik Berbasis Komputer untuk Orang-orang Non Statistik. Jakarta: Elex Media Komputindo.

[3] Nazir, Moh. 2005. Metode Penelitian. Bogor: Ghalia Indonesia.

[4] Riana, Dwiza. 2012. Statistika Deskriptif Itu Mudah. Tangerang: Jelajah Nusa.

[5] Supranto, J. 2009. Statistik : Teori dan Aplikasi, Edisi Ke-tujuh, Jilid 1. Jakarta: Erlangga.

[6] Santoso, Singgih. 2006. Seri Solusi Bisnis Berbasis TI : Menggunakan SPSS dan Excel untuk mengukur Sikap dan Kepuasan Konsumen. Jakarta: Elex Media Komputindo.

[7] Antara, Nyoman Semadi. 2012. Pengolahan dan Analisis Data. Denpasar: Universitas Udayana

[8] Ambarwati, Dwi. 2012. Analisis Pengaruh Motivasi Kerja, Pendidikan, dan Pelatihan Terhadap Kinerja Pegawai Badan Kepegawaian Daerah Kabupaen Tulungagung. Jurnal OTONOMI. Vol.12, No.1, Januari 2012.

[9] Arikunto, Suharsimi. 2002. Prosedur Penelitian Suatu Pendekatan Praktek. Edisi Revisi V. Jakarta: Rineka Cipta.

[10] Azwar, Saifuddin. 2004. Reliabilitas dan Validitas. Yogyakarta: Pustaka Pelajar Offset.

[11] Direktorat Tenaga Kependidikan. 2008. Pengolahan dan Analisis Data Penelitian. Jakarta: Direktorat Jenderal Peningkatan Mutu Pendidik dan Tenaga Kependidikan Departemen Pendidikan Nasional.

[12] Sukestiyarno. 2012. Olah Data Penelitian Berbantuan SPSS. Semarang: Universitas Negeri Semarang

[13] Karuktikum Stnia, Anita dkk. 206. Praktikum Statistika. Tegal: Program Studi DIII Akuntansi Politeknik Harapan Bersama.

[14] Riduan, dkk. 2006. Rumus Dan Data Dalam Aplikasi Statistika. Bandung: Alfabeta.

[15] Santoso, Singgih. 2000. Buku Latihan SPSS Statistik Parametrik. Jakarta: PT Flex Media Komputindo. 